\title{
The Flora of Desecheo Island, Puerto Rico
}

\author{
Roy C. Woodbury, Luis F. Martorell, and José C. García Turlurí
}

\section{INTRODUCTION}

A report on the flora of Puerto Rico and the Virgin Islands was published during the period 1923 to 1930 as volumes V and VI of the Scientific Survey of Porto Rico and the Virgin Islands in 8 parts (4 parts to each volume). The first four parts of volume $V$ and parts 1,2 and 4 of volume VI are by N. L. Britton and Percy Wilson (8). ${ }^{2}$ Part 3 of volume VI included the end of part 2 and an Appendix on the Spermatophyta; most of the text however covered the Pteridophyta (ferns and fern-allies) written by William R. Maxon (18).

Numerous citations occur in this monumental work to the flora of smaller islands and keys adjacent to Puerto Rico, namely: Vieques, Culebra, Mona, Muertos, Icacos, and Desecheo. Dr. Britton and his colleagues visited many of these islands; often making only superficial surveys and without devoting enough time to the collection of plant material. It also must be noted that several of these islands were visited but one time and this of ten during dry periods of the year. Our knowledge of the flora for each of these areas thus was incomplete.

With such gaps in scientific knowledge in mind, the present authors decided to revise the flora of these islands and keys. This project is initiated with the present paper on the vegetation of Desecheo Island. We believe that this and other similar papers to follow will contribute much to a better knowledge of the flora of the Caribbean-Antillean Region, and may encourage further studies in other Caribbean areas.

${ }_{1}$ Taxonomist, Department of Phytopathology and Botany; Entomologist and Assistant Litomologist, respectively, Department of Entomology, Agricultural Experiment Station, Mayaguiez Campus, University of Puerto Rico, Río Pieciras, P.R. The authors express gratitude to Mr. R. P. Briggs, L.S. Geological Survey, San Juan, P.R. for gaining permission of the Director, U.S. (ieological Survey, to use the 1966 preliminary map of Desecheo, for corrections and additions regarding the geology of the Island and for supplying historical information on the origin of the name 1)esecheo. We also are indebted to Chancellor José L. Arrarás and 1)r. Máximo Cerame Vivas, Director of the Marine Biological Laboratory, Mayagüez Campus, University of Puerto Rico, for transportation by the molonave "Carite" to Desecheo.

2 Italic numbers in parentheses refor to Literature Cited, page 504-5. 


\section{ORIGIN OF THE NAME}

Through the kindness of Victor M. Seiders, Geologist of the U. S. Department of the Interior (Geological Survey) at Washington, D.C. and from a letter (20) he wrote to Mr. Reginald P. Briggs, Geologist at the Hato Rey, Puerto Rico, office, we have obtained interesting historical information on the origin of the name given this little island, Desecheo.

The name is shown on many $16 \mathrm{th}, 17 \mathrm{~h}$, and 1Sth century maps of the World and of the Caribbean area. The oldest map, drawn by Juan de la Cosa, is dated in 1500 and probably was started in that year but completed in 1503 or 1504 . This map, however, does not identify the Island by the name Desecheo. Instead, the name Zecheo appears at about the same longitude on the coast of Venezuela, referring either to a small island or cape.

La Cosa's map was not discovered until the 19th century. It is hand drawn on cowhide and not printed and for that reason believed not to have influenced later map makers. Mr. Seiders is of the opinion that Zecheo probably is the original Spanish name for the Island. It is possible that La Cosa simply put the name in the wrong place.

The Turin map of the World (circa 1523) shows Desecheo as Secheo. Use of the letter $S$ instead of $Z$ probably has no significance. At that time the use of these two letters in Spanish was not formalized and they were written interchangeably. The Wolfenbüttel map (1525-1530) shows Desecheo as Zecheo. A 1569 Mercator map ralls the Rincón Península, $C$. Zecheo. A 16th century Portuguese map calls the island Zecheo. Desecheo probably resulted from merging the last two words of Isla de Zecheo.

The first references to the name Desecheo as such are found on a 16th century Portolan chart, and a 17 th century map by Fernández Valdelomar.

The French writer and traveller, Father Labat, in 1701 called the island "Zachee," a name which does not appear in any other map so far consulted. This is a unique version probably resulting from a misconception.

The name Desecheo also appears in an old English map compiled about 1888 by James F. Imray, F.R.G.S. Previous to it, in a Madrid map, 1842, "Carta Particular Esférica y Corográfica de la Isla de Puerto Rico," the name I. del Desecheo, appears in print. Mr. Briggs and one of the junior authors (Martorell) studied the last two maps mentioned, as well as another of Puerto Rico and the Virgin Islands, published by T. Domingo Sulsona, Mayagüez 1892, in which the name $I$ de Cicheo is clearly printed.

One of the early Puerto Rican historians, Fray Inigo Abbad y Lasierra (1) mentions the Island as "Isla del Desecheo."

Mr. Seiders believes the name may be of Indian origin. After reading Coll y Toste (9) we agree. Coll y Toste says, "according to Oviedo, Cicheo was the name given by the Indians to the little island located west of Puerto 
Rico, now known as Desecheo." In the same publication, in discussing the origin of the Indian word, he says "the name should be Sikeo, Indian word meaning 'high mountainous land;' that is, $S i$ for high; ke, for land; and $o$ for mountain.

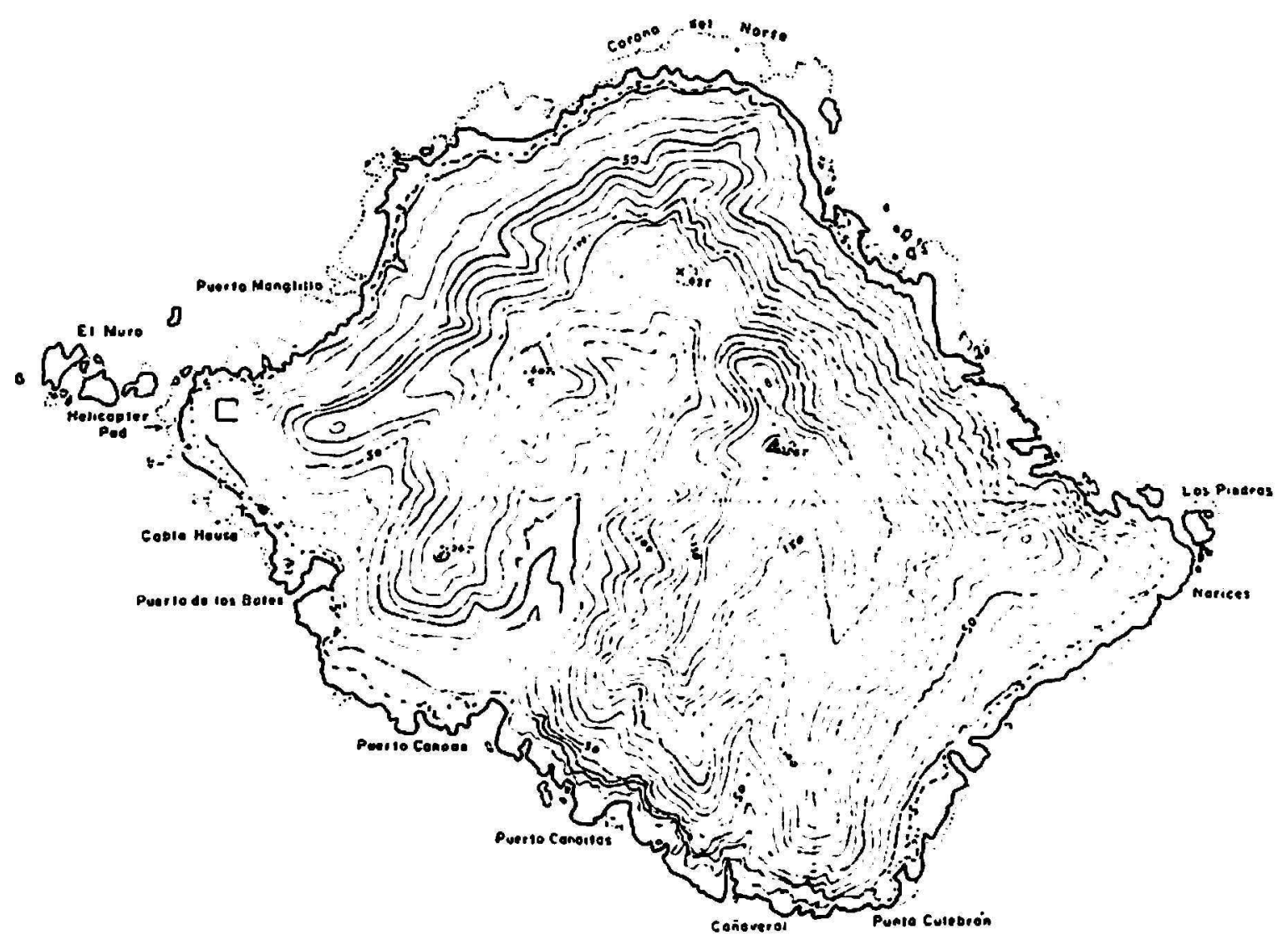

\section{ISLA DESECHEO, PUERTO RICO}

FIG. 1.-Contour map of Desecheo Island with the uames of its capes, small ports and other landmarks (Courtesy of the L.S. Ceological Survey, San Juan, P.R.).

\section{GFOLOGICAL NOTES ON DESECHEO ISLAND}

Desecheo is a very small rocky island about 1 mile square, situated in the Mona Passage, about 12 miles west of Punta Jigüero on the extreme western coast of Puerto Rico, latitude $18^{\circ} 23^{\prime}$ North and longitude $67^{\circ} 28^{\prime}$ West. Its highest peak is 676 feet according to photogrametric calculations (figs. 1,2).

Geologically, the Islind is underlain chiefly by deformed fragmental volcanic rocks of early Tertiary Period, similar to rocks exposed in the vicinity of Punta Jigüero. A raised wave-cut platform is found about 10 meters above sea level over much of its periphery. A lower wave-cut bench also occurs at 1 to 2 meters above sea level. 
Benches intermittently rim the whole island, but are preserved to a greater width and with better perfection on the northwestern and southwestern coasts where the lower bench is as much as 100 meters wide, cutting sharply across the upturned edges of the volcanic sediments and ending abruptly on its leeward side against the steep hill slopes which presumably are wave-cut cliffs. The upper platform dips seaward all around the coast

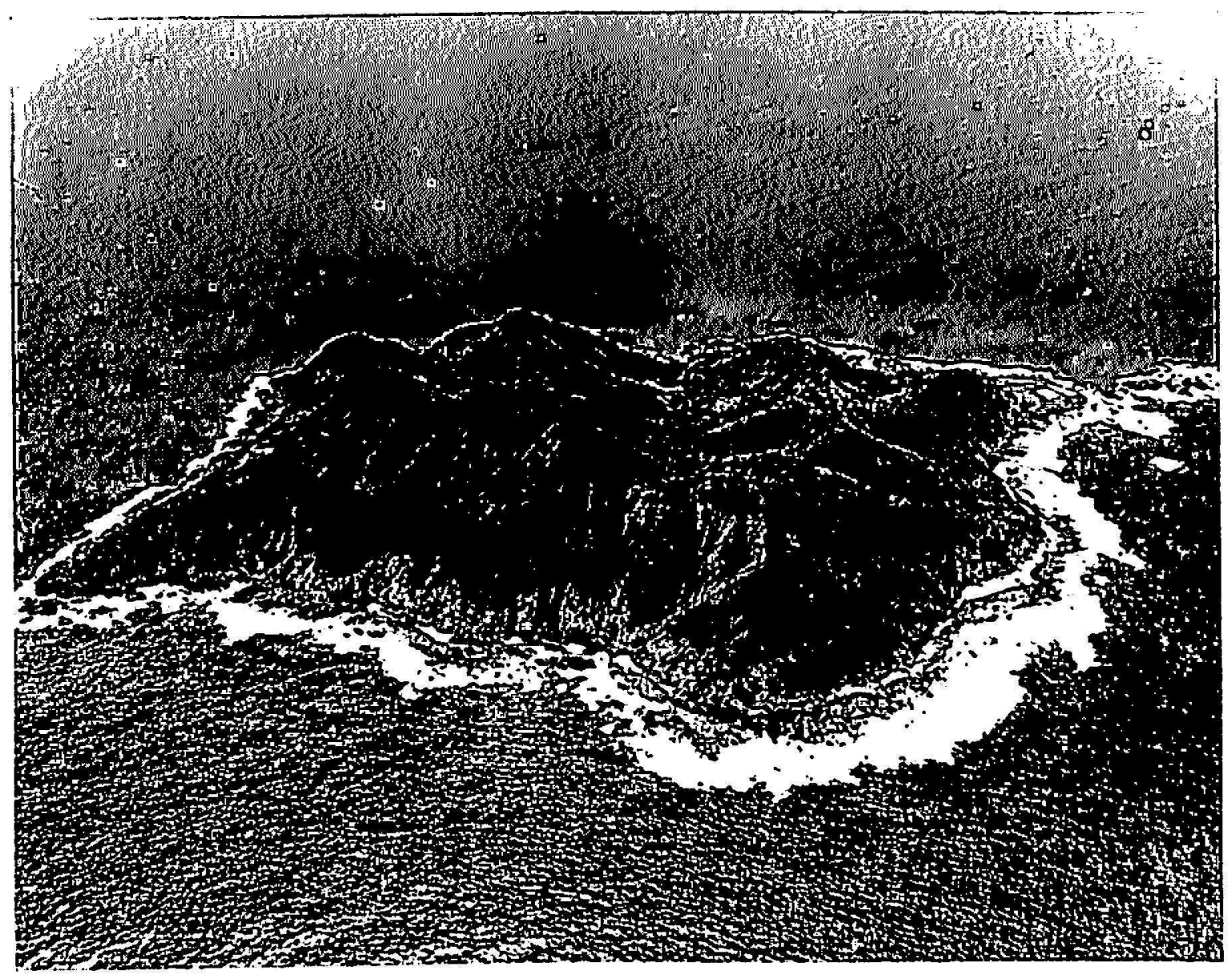

Fic. 2.-Airview of 1)esecheo Island from the northwest. At the extreme right the concrete heliport pad, in the center the large wooded valley north of Puerto Canoas.

of the Island. The surface of the upper platform is heavily coated with a thick deposit of consolidated beach material consisting of coral heads, boulders, gravel, and shells. The coral heads occasionally appear to be in position, as though still attached to the places where they grew. The evidence which this island presents is clearer than that noted elsewhere in this region and indicates a minimum tectonic uplift or eustatic change of sea level of about 10 meters.

Marine terraces and benches, more or less equivalent in elevation to the Upper Desecheo (13) bench, are found at a few places in the general area, most notably on the east side of Isla de Mona. Evidence for benches at the 
1- to 2-meter elevation of the Lower Desecheo bench is widespread along the western and northern coasts of Puerto Rico.

\section{EARLY EXPLORATIONS}

The Great Admiral, Christopher Columbus, doubtlessly was the first white man to see Desecheo, during his second visit to the New World. He discovered Puerto Rico on November 19, 1493, and anchored his galleons in the Bay of Aguada (5). He departed with his fleet the morning of November 22 on a westerly route for Hispaniola, during which he had a closer view of the small island.

The famous French traveller and writer, Jean Baptiste Labat, called the island Zachee. He spent most of his 12 years in the Antilles, 1693 to 1705, at the French possessions of Martinique and Guadeloupe, but he also during this time visited the Grenadines, Barbados, St. Christoper, St. Eustatius, St. Bartholomew, Saba, St. Martin, St. Thomas, St. Croix, and Vieques Island. He very carefully recorded the geography and took notes on the inhabitants, animals, plants, crops, and industries of all the places visited, information which became very useful at the time of its publication. While travelling from Santo Domingo toward the west coast of Puerto Rico in 1701, he reported, Vol. 7 (14): 311, "On Monday 11th of April, we saw Mona, Monique and Zachee..." but furnishes no more information about the latter island.

Our earliest Puerto Rican historian, liray Iñigo Abbad y Lasierra (1), referring to Desecheo wrote: "In front of the port of Añasco, two leagues farther is the island of Desecheo, which has three leagues of circumference. It is uninhabited although covered by trees, has many wild goats which are hunted by smugglers, as well as sea lobsters, shells and other seafood which is very abundant there. ..."

Alexander Wetmore (2S) refers to the early history of Desecheo as follows: "The island of Desecheo called Zachee by Labat, was well known to early voyagers as a landmark in Mona Passage, but it was not visited by a naturalist, so far as I am aware, until Bowdish landed there, June 24, 1900 and again sojourned there from July 6 to 10, 1901, though Gundlach (11), passing near the island in 1874 , on one of his voyages from Cuba, had remarked on the large number of seabirds seen near it."

Referring again to Bowdish, Dr. Wetmore remarks: "During this same period Mr. B. S. Bowdish was devoting as much time to the study of the avifauna of Porto Rico as his military duties would allow. His observations on the Island extended from February 22, 1899 to February 16, 1900, and from May i, 1900 to October 24,1901 . In the course of his second stay on the Island he visited also Aguadilla and continued his observations at Mayagiiez." 
Bowdish published various papers $(2,3,4)$ based on these trips to Desecheo; in one, he called the Island De Sicheo, writing its name as it sounded phonetically to a North American.

Dr. Alexander Wetmore, a well known American ornithologist, was the next visitor to Desecheo. He stayed on the Island June 13-16, 1912, and included his observations on the bird life he found there in two papers $(22,28)$ on the bird fauna of Puerto Rico published in 1916 and 1927.

The first botanical explorations made in Desecheo, according to Dr. N. L. Britton (6) were conducted by Mr. W. E. Hess and Prof. F. L. Stevens, who spent 2 days on the island toward the end of May 1913. Almost nine months later, Dr. Britton and a small party of scientists visted Puerto Rico, as well as Desecheo, for further botanical explorations. They stayed on Desecheo for the short period February 17-20, 1914.

Britton $(6,7)$ reported a total of 90 plant species from his botanical investigations on Desecheo in 1913 and 1914. In his final work on the Botany of Porto Rico and the Virgin Islands, however, published 16 years Iater (8), he cites only 63 species. Such common cacti as Opuntia dillenii and $O$. repens could not be overlooked by him. In his account of his two trips, he made reference to eight species of cacti on the Island, although he records only five. We found nine species to occur there.

A group of American entomologists interested in collecting insects: H. G. Barber, H. E. Crampton, F. F. Lutz, A. J. Mutchler and F. E. Watson, visited Puerto Rico, Mona and Desecheo, collecting on the latter locality February 18-20, 1914.

Bela Hubbard (12) conducted geological investigations in the western districts of Puerto Rico, including Desecheo, in the summer of 1916, although the exact date of his visit to the Island is not stated. He was the first to recognize the two marine benches which he labelled the Upper Desecheo Stage and the Lower Desecheo Stage (18).

Parke H. Struthers, another ornithologist, visited Desecheo in January 1922 and again in 1926. In 1923 he published his observations on the bird life of Puerto Rico in Auk (21) recording his 18-month experiences in western Puerto Rico and on Mona and Desecheo.

Dr. Stuart Taylor Danforth, professor of Zoology and Entomology at the College of Agriculture and Mechanic Arts at Mayagüez, accompanied by some students, spent 4 days (May 7 to 9, 1927) on Desecheo Island, making valuable ornithological observations published Jater in the Journa] of the Department of Agriculture of Puerto Rico (10).

There are no records of other visits to Desecheo for scientific purposes from 1927 to 196i5. We believe the Island was used from 1940 to 1952 as a fractice target for aterial bombardment, evidence of which is still widespread. Shattered, pulverized rock is found on the eastern ridges and cliffs, 
and segments of bombs and shells are common. Unexploded ordnance is discovered occasionally. Thereafter and until 1960, we understand Desecheo was a survival area for the U.S. Air Force.

Title to the Island was transferred about 1965 to the U.S. National Institute of Health, Section on Primate Ecology and a small colony of Rhesus monkeys was established there in July 1966. Work related to this colony was under the general direction of Dr. Ronald E. Myers, Chief, Laboratory of Perinatal Physiology, National Health Institute, San Juan, P.R. Dr. John A. Morrison and Mr. Carlos Nagel made frequent visits to Desecheo (19) in the course of preparing and managing the colony.

\section{RECEN'T SCIENTIFIC EXPLORATION}

Desecheo was not explored botanically further until a group of scientists composed of George W. Miskimen, Entomologist and Director of the Entomology Pioneering Laboratory at the Mayagüez Campus; Darío Galindo, a graduate student in Entomology of Cclombian nationality, Clyde F. Smith, Research Professor in Entomology, North Carolina State University at Raleigh, Roy Woodbury, Taxonomist, and Luis F. Martorell, Entomologist, the last two from the Agricultural Experiment Station at Río Piedras, visited it for a day (April 5, 1967) to collect plant material and make entomological observations.

A second visit was made July 12--July 14, 1968 by Roy Woodbury, Luis F. Martorell, J. García Tudurí, S. Medina Gaud, (the last two, Entomologists at the Agricultural Experiment Station at Río Piedras) and Kïm Woodbury, Roy's son, a student at Coral Gables High School, Miami, Florida.

There is no fresh water on the island and it is inhabited only by wild goats and recently introduced Rhesus monkeys which have become the sole permanent dwellers. Two species of boobies occur there; the brown booby, Sula leucogaster leucogaster (Boddaert), "hich nests on the rocks and on open ground, and the red-footed booby, Sula sula sula (L.), which nests usually in the taller trees, especially "almácigo", Bursera simaruba (I.) Sarg. This limited fauna has a very positive effect on the vegetation of the Island.

The Island vegetation consists in general of a seasonal deciduous woodland and a thorny cactus scrub, except for the coastal communities where one encounters fluctuating succulent shrubs, the littoral shrubs or woodland, and an occasional grassy area of Panicum maximum or Aristida.

The more humid valleys and lower slopes maint ain a deciduous woodland of two stories of trees, a poorly to well developed shrub layer and a seatsonal herb layer.

The upper tree layer consists mostly of the dominant Bursera simaruba, 
and the less dominant Ficus cilrifolia, and a few rare species such as Celtis trinervia and Torrubia fragrans. The larger trees (Bursera) occasionally reach a trunk diameter of 30 inches and 40 feet in height, but usually they are 1 foot in diameter by 30 feet high.

The lower tree layer consists of numerous species of evergreen to semievergreen trees, 2 to 6 inches in trunk diameter and 12 to 20 feet in height. Some of the more dominant species are: Eugenia thombea, $E$. axillaris, Krugiodendron ferreum, Bourreria succulenta, Torrubia discolor, which is very common, Capparis spp., Amyris elemifera, Pithecellobium unguis-cati, Citharexylum fruticosum, and four cacti: Lemaireocereus hystrix, Pilosncereus royenii, Consolea moniliformis, and Harrisia portoricensis. Some of the less common species are Erylhroxylon brevipes, Guellarda elliptica, Savia sessilifora, Clusia rosea, Bumelia obovala, Colubrina reclinata, and Morrisonia americana.

The following lianas frequently climb the trees: Doxantha unguis-cati, Stigmaphyllon periplocifolium, Cissus sicyoides, the spiny woody vine, Cellis iguanea, and a few herbaceous species such as Ipomoea triloba and Passiflora suberosa.

The shrub layer, which is rather dense to completely open, is composed predominantly of Plumbago scandens, Cracca caribaea, Celosia nitida, Iresine angustifolia and Iresine diffusa, Opuntia triacantha, Petiveria alliacea and Solanum racemosum.

The herbaceous-like shrub layer has been greatly modified by the feeding of goats, but irregular patches of herbs may be seen during the rainy season. These represent the following species: Trichachne insularis, Setaria setosa, Sila procumbens, S. glabra, Paspalum laxum, Panicum fasciculatum, Pappophorum pappiferum, and Commelina virginica.

The epiphytes are very scarce but one may encounter the two species of Tillandsia previously reported from Desecheo; T'. utriculata and T. recurvala. No orchids were found either by us or by Dr. Britton; however, Britton recorded one species of fern, Cheilanthes microphylla, which we did not see.

A scrubby to cactus vegetation, with very little or no layering of the tree species, is found on the ridges and wind-exposed barren slopes (fig. 3). This type of vegetation is seldom over 10 to 12 feet high and may grow to only 2 to 4 feet on the windward northeast slopes. Bursera is frequently seen again in the more protected ridges but there is a preponderance of the following species: Torrubia discolor, Eugenia axillaris, Capparis flexuosa, Bumelia oborala var. Krugii, Pithecellobium unguis-cati, Erithalis fruticosa, and at the same time the four cacti mentioned.

There also are several rare species, such as Securinega acidoton, Hippomane mancinella, Foresteria segregata, Coccoloba uvifera and Duranta repens, 
which make up the major proportion of the dwarfed trees. The shrub layer is prominent and consists of many shrub-like vines, such as Toumefortia microphylla, Sligmaphyllon periplocifolium, Cynanchum grisebachianum, Cardiospermum corindum, Jacquemontia nodiflora, and $J$. pentantha. The regular shrubs are represented by Celosia nitida, Eupatorium odoratum, Solanum racemosum, Talinum paniculatum, Lantana involucrata, Euphorbia

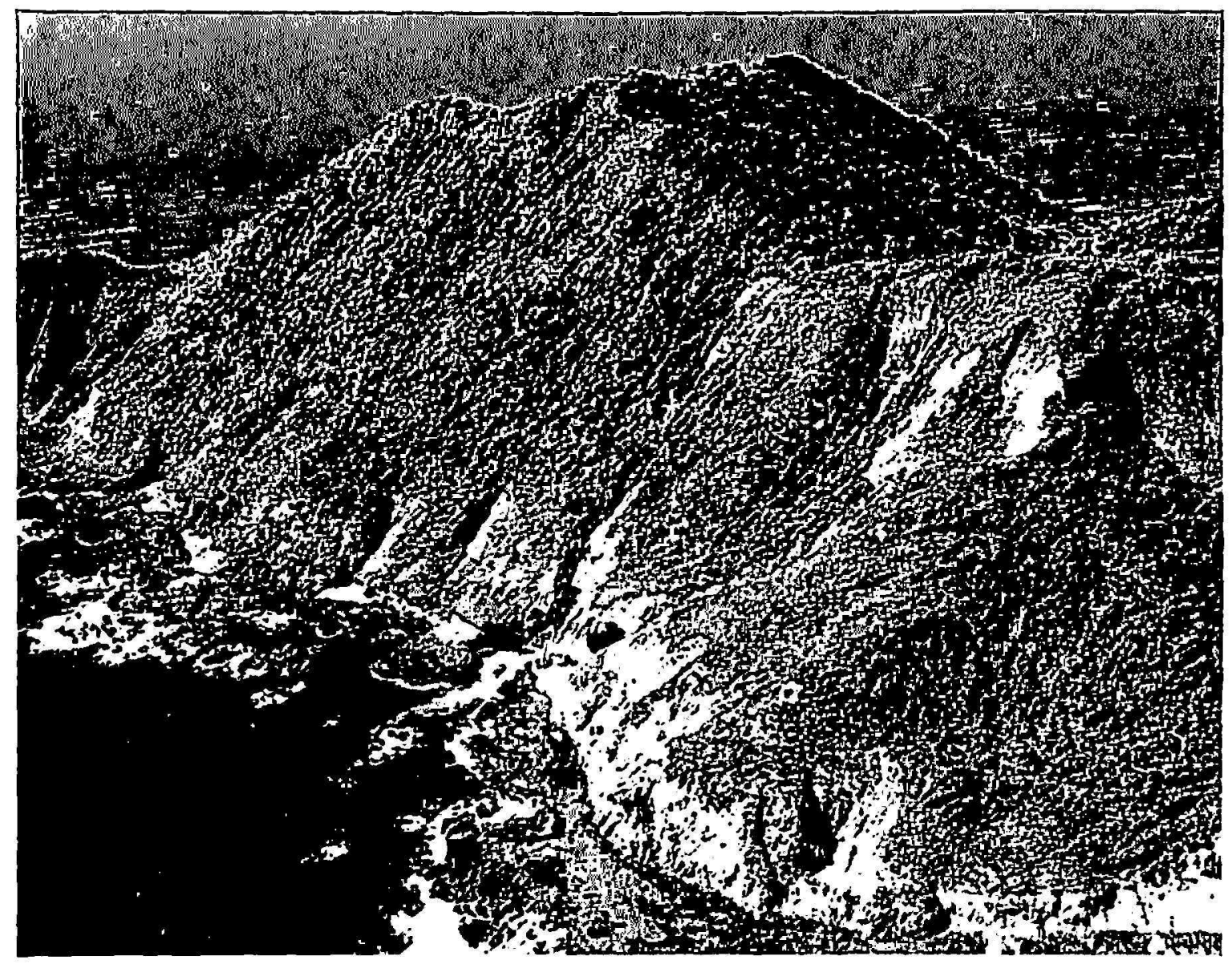

FIG. 3-Scrubby to cactus vegetation on the ridges and wind-exposed barren slopes such as this, on the northwest end of Jesecheo. At the very (op, the highest peak of the Island; immediately at its right, the latge wooded valley.

articulata (mostly coastal), Waltheria indica, Melochia tomentosa, Desmanthus virgatus (sometimes herbaceous), and Opuntia dillenii (usually found infested in large patches by the cactus moth, Cactoblastis cactorum (Berg.).) The herbaceous layer is well represented by most of the grasses present on the Island, plus a large number of succulent and regular herbs. Weedy species are also frequently seen in the more open areas.

The beach flora is poorly developed due to the very limited area of shifting sand and pebbles which is formed only on the leeward southwest shore. The flora in this area is particularly represented by the following: 
Amaranthus viridis, Boerhaavia diffusa, Capparis flexuosa, Coccoloba uvifera, Cyperus planifolius, Euphorbia articulala, Erithalis fruticosa, Hippomane mancinella, Ipomoea tuba, Opuntia repens, O. dillenii, Panicum adspersum, Portulaca oleracea, Phyllanthus amarus, Sporobolus virginicus, and Sesuvium portulacastrum. From the name "El Manglillo" given one of the western points, one would expect to see some mangrove species growing there. None were reported by Britton, however, and we did not have enough time to find out.

Specimens of the plant material we collected on Desecheo during our trips to the Island will be deposited in the herbaria of Harvard University, New York Botanical Garden, the U.S. National Herbarium of the U.S. Department of Agriculture and the Agricultural Experiment Station of the University of Puerto Rico at Río Piedras.

The authors have used the taxonomic nomenclature of Britton and Wilson $(8)$ as revised recently by Liogier $(15,16)$ in preparing this check list.

\section{PLANTS OF DESECIIEO ISLAND}

\section{GRAMINEA E}

\section{* Andropogon pertusus (L.) Willd. ${ }^{3}$}

Amphilophis ischaemum (L.) Nash.4-Occurs along the rocky coastline (fig. 4) bordering the interior valley in Puerto de los Botes; appears to be a recent introduction, not common. Woodbury, Martorell, García D 121.5 * Aristida adscensionis L.

Observed along the northern ridge north of the large interior valley; locally common. Woodbury and Martorell D 65, D 99.

* Cenchrus brownii R. and S.

Cenchrus viridlis Spreng.-Along coastline near l'uerto de los Botes; not common. Woodbury, Martorell, García D 83.

* Cenchrus equinatus $L$.

Dr. Clyde F. Smith observed the first specimens near the coast in the areal west of Puerto Canoas on April 5, 1967; fairly abundant along the coast in open area.

* Cenchrus myosuroides HBK.

Cenchropis myosuroides (HBK) Nash-Observed by Woodbury and Martorell in the area west of Puerto Canoas, common along the coastal

${ }^{3}$ Names preceded by asterisks indicate new plant records for Desecheo Island.

+ Plant names in italies are those used by Britton and Wilson in their publication on the Flora of Porto Rieo and the Virgin Islands (8) and now in syononym. Plant names in boldface roman are the correct and accepted names.

s Numbers preceded by a l) following collectors' namos, refer to the specimen number in the Herburium. 
line between Puerto Canoas and Puerto de los Botes; in open areas. Woodbury, Martorell, García D 82, D 107.

* Digitaria adscendens (HBI.) Henr.

Syntherisma sanguinalis (L.) Dulac.-Observed by Woodbury and Martorell along the rocky shoreline west of Puerto Canoas, also fairly common along the rocky shores of the west coast. Martorell, Woodbury, García D 46, D 96.

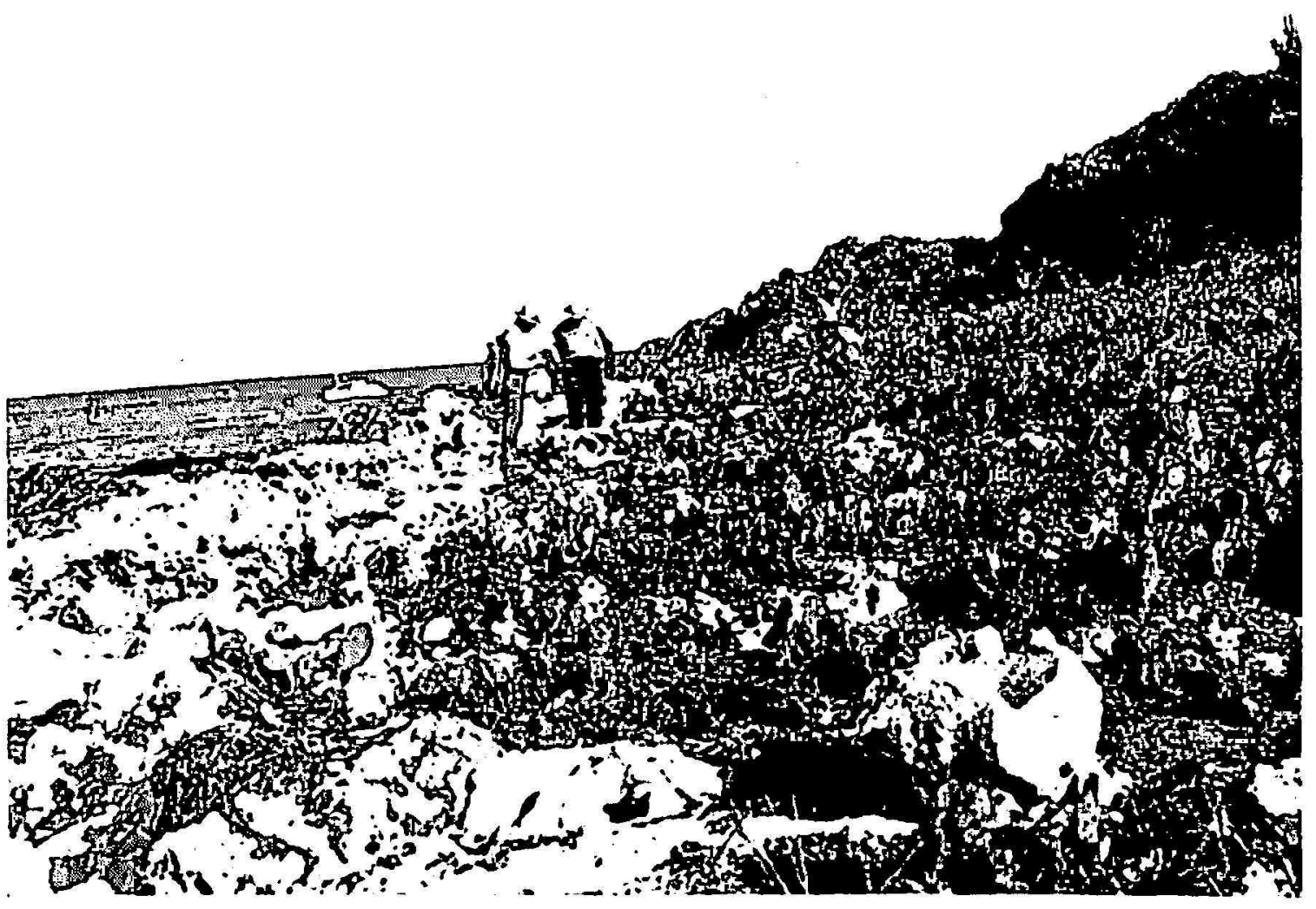

FIG. 4.-Collecting plants along the rocky shores bordering the interior valleys between Puerto Canoas and Puerto de los Botes; the motonave Carite, in the hackground.

\section{* Panicum adspersum Trin.}

Observed by Martorell and Woodbury west of P'irate's Cove along the rocky shores; not common. Martorell and Woodbury D 103.

* Panicum fasciculatum Sw.

Occurs along the coast west of Puerto de los Botes but not common; also in large patches in two places in the smaller valley in Puerto de los Botes. Woodbury and Martorell D 6 (66.

* Panicum maximum Jacg.

On slopes and rocky shores west of Puerto de los Botes near the heliport pad; fairly abundant. Woodbury and Martorell D 122. 


\section{Pappophorum pappiferum (Lam.) Kunt ze}

Pappophorum alopecuroideum Vahl-Recorded by Britton and Wilson, Vol. V, p. 72. Observed by Woodbury and Martorell on the ridge north of the large interior valley; also common along the rocky shores and mountain slopes of the southwest areas. Woodbury and Martorell D 22, D 68 .

Paspalum laxum Lam.

Paspalum glabrum Poir.-Recorded by Britton and Wilson Vol. V, p. 39. Observed by Woodbury and Martorell on top of ridges on north coast; along the coast in the southwest area. Woodbury, Martorell, García D 27, D 123.

* Rhynchelytrum repens (Willd.) G. E. Hubb.

Tricholaena rosea Nees; Tricholaena repens Nees-Along the coast west of Puerto de los Botes, near the large wooden tank used as a water supply for the Rhesus monkeys; probably a recent introduction in Desecheo. Woodbury and Martorell D 124.

* Setaria lejophylla (Nees) Iiunth

Cited by Brother Alain Logier (15) in 1965, p. 319, as present on Desecheo as well as at Ponce, Puerto Rico.

* Setaria rariflora Mikan

Chaetochloa rariflora (Mikan) H. and C.-Observed by Woodbury and Martorell in large interior valley north of Puerto Canoas; on top of ridge on north coast; also, along the rocky shores of the southwest coast. Woodbury and Martorell D 97.

Setaria setosa (Sw.) Beauv.

Chaetochloa setosa (Sw.) Scribn.-Recorded by Britton and Wilson, Vol. V, p. 56. Observed by Woodbury and Martorell at landing beach (Trap Bay) at Puerto Canoas; also, on the high ridge of the north coast. Woodbury and Martorell D 81, D 98.

Setaria utowanaea (Scribn.) Pilger

Panicum utowanaeum Scribn.-Recorded by Britton and Wilson, Vol. V, p. 43. Observed in the interior valley north of Puerto Canoas; at end of same valley ascending the northern ridge; also, on top of the ridge. Woodbury and Martorell D 32, D 139.

Sporobolus virginicus (L.) Kunth.

Recorded by Britton and Wilson, Vol. V, p. 64. Observed by Woodbury and Martorell along slopes near the coast on the northern coast.

Trichachne insularis (L.) Nees

Valota insularis (L.) Chase-Recorded by Britton and Wilson, Vol. V, p. 32. Observed by Woodbury, Martorell, and Garcia along the coastline west of Puerto Canoas, also in the interior valley north of this area; very common grass.

* Uniola virgata (Poir.) Griseb.

Observed on top of the ridge on the northeast coast by Woodbury 
and Martorell; fairly common from the rocky shores of the southwest to the interior valleys and ridges. Woodbury, Martorell, Garcia D 119.

CYPEKACEAE

\section{* Cyperus ligularis L.}

Observed by Woodbury and Martorell west of Puerto Canoas growing on the rocky soil near the beach; not seen during our second trip.

* Cyperus planifolius L. C. Richard

Observed by Woodbury and Martorell with the other species west of Puerto Canoas. Woodbury, Martorell, García D 51, D 101.

\section{BROMELIACEA}

\section{* Tillandsia recurvata $\mathrm{I}$.}

Observed by Woodbury and Martorell at end of large interior valley north of Puerto Canoas, on trees and attached to the trunk of spiny cacti growing along the ridge of the northern coast; two specimens collected from the trunk of Consolca moniliformis (L.) Britton. Woodbury and Martorell D 111.

\section{* Tillandsia utriculata $L$.}

On top of the ridge on the northern coast attached to trunks of spiny cacti out of reach of goats and monkeys, particularly on Consolea moniliformis; a juvenile specimen collected. Woodbury and Martorell D 37.

\section{COMMLLINACEAE}

\section{Commelina virginica $L$.}

Commelina elegans HBK.--Recorded by Britton and Wilson, Vol. V, p. 145. Observed by Woodbury and Martorell at the landing area in Trap Beach at Puerto Canoas; common near the coast and in the interior valleys, ascending to the slopes and the higher ridges; surprisingly, many exuberant plants were observed under the shade of trees on the higher ridges, but not eaten by goats or monkeys. Woodbury, Martorell, García D 14is.

\section{PIPERACEAE}

\section{Peperomia humilis (Vahl) A. Dietr.}

Recorded by Britton and Wilson, Vol. V, p. 228. Not seen by us on our trips to Desecheo but possibly present at higher elevations near the high peak on the east center of the Island.

\section{ULMACEAE}

Celtis iguanea (Jacq.) Surg.

Momisia iguanea (Jacr.) Rose and Standley-Recorded by Britton and Wilson, Vol. 5, p. 234. Observed climbing vigorously on trees and 
shrubs by Woodbury and Martorell in large interior valley north of Puerto Canoas. Aside from the cacti, this is the most hazardous species occurring in the valleys to humans due to its spines. Woodbury, Martorell, García D 73.

\section{* Celtis trinervia Lam.}

Large trees on the interior valley north of Puerto Canoas with trunk diameters of 10 to 14 inches and over 40 feet in height. Woodbury and Martorell D 14, D 142.

\section{MORACEAE}

\section{* Ficus citrifolia P. Mill.}

Ficus laevegata Vahl-Observed by Woodbury and Martorell in valley north of Puerto Canoas; also, in other interior valleys as well as along the rocky shores and even on the ridges north and northeast; common. Woodbury, Martorell, García D 38.

\section{POLYGONACEAE}

Coccoloba uvifera (L.) Jacq.

Coccolobis uvifera (L.) Jacq. - Recorded by Britton and Wilson, Vol. V, p. 268. Large patch of trees west of Puerto Canoas near the coast; not common. Woodbury, Martorell, García D 50.

\section{AMARANTHACEAE}

Amaranthus dubius Mart.

Recorded by Britton and Wilson, Vol. V, pp. 277-S. Not seen by us during our visits to Desecheo.

* Amaranthus viridis L.

Amaranthus gracilis I.--Along the coastline in open situations, sometimes in half-shade under bushes and trees in the interior valleys; fairly abundant. Woodbury, Martorell, García D 94, D 150.

* Achryanthes aspera L.

Centrostachys indica (L.) Standley; Centrostachys aspera (L.) Standley. A common species on the underbrush in the interior valleys, along the coast, and on ridges and slopes. Woodbury, Martorell, García D 78, D 104. Celosia nitida Vahl

Recorded by Britton and Wilson, Vol, V, pp. 274-5. Near the coast west of Puerto Canoas, common in the interior valleys particularly under shady situations. Woodbury, Mirtorell, García D 16, D 87.

Iresine angustifolia Euph.

Recorded by Britton and Wilson, Vol. V, p. 282. Along the coastal areass west of Puerto Canoas, also a natural underbrush plant in the valley's; very common. Woodbury, Martorell, Garcia D 5, D 147. 
* Iresine diffusa $\mathrm{H}$. and $\mathrm{B}$. ex Willd.

Iresine celosia L. Seen at the end of large interior valley north of Puerto Canoas. Woodbury and Martorell D 15.

\section{NYCTAGINACEAE}

Torrubia discolor (Spreng.) Britton

Recorded by Britton and Wilson, Vol. V, pp. 286-7. A fairly common species in the interior valleys and on mountain slopes and ridges. Woodbury, Martorell, García D 53, D 68, D 6.

* Torrubia fragrans (Dum.-Cours.) Standley

Large trees in the valleys; rare. Woodbury and Martorell D 63. Boerhaavia diffusa $\mathrm{L}$.

Boerhaavea coccinea Mill.-Recorded by Britton and Wilson, Vol. 5, p. 285. In open areas, mostly near the coast between Puerto de los Botes and Puerto Canoas; in flower and fruit July 12, 1968. Woodbury, Martorell, García D 55, D 100.

\section{PHYTOLACCACEAE}

\section{* Petiveria alliacea $\mathrm{L}$.}

A very common weed in the underbrush in the interior valleys; not seen during our first trip in April, 1967, due apparently to the extreme drought occuring at the time; very common and luxuriant in July, 1968. Woodbury, Martorell, García D 57.

* Rivina humilis L.

Common under shady situations in the valleys, not seen by us during our first trip. Woodbury, García, Martorell D 67.

\section{AIZOCEA E}

\section{* Sesuvium portulacastrum $\mathrm{L}$.}

On the rocky shores west of Puerto Canoas; locally abundant. Woodbury, Martorell, García D 59, D 132.

* Trianthema portulacastrum $I$.

Along the coastline, also in the valleys; rare. Woodbury, Martorell, García D 54.

\section{PORTULACACEAE}

\section{Portulaca oleracea $\mathrm{L}$.}

Recorded by Britton and Wilson, Vol. V, p. 299. Along the coastal area between Puerto de los Botes and Puerto Canoas; fairly common. In flower July 12-13, 1968. Woodbury, Martorell, Garcíi D 26, D 69. 
Talinum paniculatum (Jacq.) Gaertn.

Recorded by Britton and Wilson Vol. V, p. 298. Quite common at Trap Beach, Puerto Canoas, and along the coastal area of the southwest of Desecheo, also on ridges in more or less open areas. Woodbury, García, Martorell D 25, D 80.

\section{CAPPARACEAE}

\section{Capparis cynophallophora $L$.}

Recorded by Britton and Wilson, Vol. V, pp. 333-4. One of the most abundant trees of the interior valleys; also present on mountain slopes and occasionally on the ridges. Woodbury, García, Martorell D 62.

Capparis flexuosa $\mathrm{L}$.

Recorded by Britton and Wilson, Vol. V, pp. 334-5. Mostly along the shore between Puerto de los Botes and Puerto Canoas; in buds and flowers July 12-13, 1968. Woodbury, Martorell, García D 18, D 144.

*Capparis indica (L.) Fawc. and Rendle.

Seen on top of the northern ridge, but most common in the valleys. Woodbury and Martorell D 110, D 155.

Morisonia americana $L$.

Recorded by Britton and Wilson, Vol. V, p. 336. On top of the ridge in the north coast, also one tree in the valley near Celtis trinervia trees; rare. Woodbury and Martorell D 90.

\section{LEGUMINOSAE-MIMOSOIDEAE}

Desmanthus virgatus (L.) Willd.

Acuan virgatum (L.) Medic.; $A$. depressum (H. \& B.) Kuntze; $A$. insulare Britton and Rose.-Recorded by Britton and Wilson as $A$. insulare, Vol. V, p. 539. On the ridge of the north coast, rare. Woodbury and Martorell D 108, D 135.

Pithecellobium unguis-cati (L.) Benth.

Pithecellobium unguis-cati (L.) Mart.-Recorded by Britton and Wilson, Vol. V, p. 348. A very common species in the valleys, on mountain slopes and ridges; at times forming impenetrable barriers difficult to cross even with aid of a machete. Woodbury, Martorell, García D 76.

\section{LEGUMINOSAE-CAESALPINIOIDEAE}

Cassia aeschynomene DC.

Chamaecrista aeschinomene (DC.) Greene.-Recorded by Britton and Wilson, Vol. V, p. 368. Not seen by us on Desecheo.

Cassia occidentalis $\mathrm{L}$.

Ditremexa occidentalis (L.) Britton and Rose-Recorded by Britton and Wilson, Vol. V, p. 372. Not seen by us on Desecheo. 


\section{LEGUMINOSAE-PAPILIONOIDEAE}

Cracea caribaea (Jacq.) Benth.

Benthamantha caribaea (Jacq.) Kuntze.-Recorded by Britton and Wilson, Vol. V, p. 394. Along the coast between Puerto de los Botes and Puerto Canoas; also in the large valley north of Puerto Canoas; not very common. Woodbury, Martorell, Girrcía D 31, D S5.

* Galactia dubia DC.

On Trap Beach at Puerto Canoas, also on ridge on the northern coast; not too common. Woodbury and Martorell D 141.

* Galactia striata (Jacq.) Urban D 11.

On top of the northern ridge; not common. Woodbury and Martorell

Tephrosia cinerea (L.) Pers.

Cracca cmerea (L.) Morong.-Recorded by Britton and Wilson, Vol. V, p. 391. On the rocky shores of the southeast area and in open situations on the ridges. Woodbury, Martorell, García D 84, D 131.

\section{ERYTHROXYLACEAE}

* Erythroxylon rotundifolium Lunan

Erythroxylon brevipes DC.- In the interior valleys and on mountain slopes; not common. Woodbury, Martorell, García D 7, D 116.

\section{MALPIGHACEAE}

* Stigmaphyllon periplocifolium (Desf.) Juss.

Stigmaphyllon lingulatum (Poir.) Small-On Trap Beach at Puerto Canoas; climbing trees and bushes in the interior valleys and on the ridges also found along the coast. Woodbury, Martorell, Garcíi D 70.

\section{IRUTACEAS}

Amyris clemifera $\mathrm{L}$.

Recorded by Britton and Wilson, Vol. V, p. 453. One of the more common smaller trees in the interior valleys and on mountain slopes. Woodbury, Martorell, García D 1, D 118.

\section{BURSERACEAF}

Bursera simaruba (L.) Sirg.

Elaphrium simaruba (L.) Rose--Recorded by Britton and Wilson, Vol. V, p. 462. The largest tree of Desecheo, some of them 30 inches in trunk diameter and 40 feet high; abundant in the interior valley's, on mountain slopes and along the coastline. On April 5, 1967, boobies were nesting in large numbers on the highest branches of this tree species. Woodbury, Martorell, García D 151. 


\section{EUPHORBIACEAE}

\section{* Adelia ricinella L.}

Ricinella ricinella (L.) Britton-Seen by Woodbury and Martorell in the valley north of Puerto Canoas; not common.

\section{Chamaesyce articulata (Aubl.) Britton}

Recorded by Britton and Wilson, Vol. V, p. 505. Common along the rocky coast in open areas of the southwest, trees about 3 inches in trunk diameter and up to 18 feet high; this tree is seen usually as a bush or shrub, but growing here as small trees. It is of interest to note that plants of this species with short ( $2 \mathrm{~cm}$. long) rounded leaves and thick trunks were seen near the landing place (l'uerto Canoas). Normal leaves are not rounded, but linear to oblong linear and 3 to $6 \mathrm{~cm}$. long. Woodbury, Milrtorell, García D 88, D 112.

* Chamaesyce hirta (L.) Millsp.

On rocky soil along the coast west of P'uerto de los Botes, near the wooden tank besides the heliport; fairly common in this area. Woodbury and Martorell D 48.

\section{* Croton betulinus Vahl}

Observed by Woodbury and Martorell during their first trip to Desecheo, quite abundant in valley north of Puerto Canoas; overlooked by Woodbury, Martorell and García on their second trip.

Gymnanthes lucida Sw.

Recorded by Britton and Wilson, Vol. V, p. 495. Scattered in the interior valleys, on mountain slopes, and even on ridge tops. Woodbury, Martorell, García D 8, D 114.

Hippomane mancinella $\mathrm{L}$.

Recorded by Britton and Wilson, Vol. V, pp. 494-5. Not seen by us during our visits but possibly growing along the coastal area on the eastern or northern beaches.

\section{Jatropha gossypifolia 1.}

Adenoropium gossypifolium (L.) Pohl-Recorded by Britton and Wilson, Vol. V, p. 48i. Sot seen by Woodbury and Martorell in the first trip to Desecheo but collected later near the coast and in the large valley north of Puerto Canoas. The foliage of the plants was infected apparently by the same virus which attacks this species in Puerto Rico. A few plants also were observed in open places on slopes and ridges. Woodbury, Martorell, García D 79.

* Phyllanthus amarus Schum. and Thomn.

On top of the ridges on the northern zone and near the heliport west of Puerto de los Botes; not common. Woodbury and Martorell D 91, I) 120 . 
Savia sessiliflora (Sw.) Willd.

Recorded by Britton and Wilson, Vol. V, p. 473. In the interior valley north of Puerto de los Botes; not common. Woodbury, Martorell, García D 125.

* Securinega acidoton (L.) Fawcett

On top of the ridge on the north coast; not common. Woodbury and Martorell D 64.

\section{SAPINDACEAE}

* Cardiospermum corindum L.

Locally abundant along the rocky shores in the coastal area between Puerto de los Botes and Puerto Canoas. Woodbury, Martorell, García D 61, D 130.

\section{RHAMNACEAE}

* Colubrina reclinata (L'Her.) Brogn.

In the interior valleys along the coast; not common. Woodbury and Martorell D 36.

Krugiodendron ferreum (Vahl) Urban

Recorded by Britton and Wilson, Vol. 5, p. 533. Uncommon in the interior valley north of Puerto Canoas. Woodbury, Martorell, García D 23, D 126.

\section{* Cissus sicyoides L.}

\section{VITACEA E}

Abundant, climbing trees in the interior valleys, on mountain slopes and sometimes even on the upper ridges. Plants were very luxuriant during July 1968; in many cases, trees were practically covered by this vine. Woodbury, Martorell, García D12, D 44.

\section{TILIACEAE}

\section{Corchorus hirsutus L.}

Recorded by Britton and Wilson, Vol. V, pages 543-4. On top of the northern ridge, fairly common along the coastal area of the southwest and in the interior valleys. Woodbury, Martorell, García D 106, D 134.

\section{MALVACEAE}

* Abutilon umbellatum (L.) Sweet

At entrance of valley west of Puerto Canoas; not common. Woodbury, Martorell, García D 129.

* Bastardia viscosa (L.) HIBK.

On slope, dry soil, open sites, between P'ucrto de los Botes and Puerto Canoas; fatrly common. Woodbury, Martorell, García J) 127. 


\section{Malvastrum corchorifolium (Desv.) Britton}

Recorded by Britton and Wilson, Vol. V, p. 550. On top of ridge at end of the large valley north of Puerto Canoas, and along the rocky shores of the southwest coust; foliage infected with virus causing intense chlorosis. Woodbury, Martorell, García, D 109, D 146.

Malvastrum coromandelianum (L.) Garcke

Recorded by Britton and Wilson, Vol. V, p. 549. Along the rocky shores of the southwest coast; fairly common. Observed by Woodbury, Martorell and García.

Sida acuminata DC.

Recorded by Britton and Wilson, Vol. V, pp. 554-5. Collected on top of the ridge on the north coast during our first visit. Woodbury and Martorell, D 109.

Sida glabra Mill.

Recorded by Britton and Wilson, Vol. V, p. 554. Along the coast west of Puerto Canoas, fairly common in open sites, also along the edge of the forest and semi-open places in the valleys. Woodbury, Martorell, García D 10, D 74.

Sida procumbens $\mathrm{Sw}$.

Recorded by Britton and Wilson, Vol. V, p. 553. In dry areas near the coast between Puerto de los Botes and Puerto Canoas; not common. Woodbury, Martorell, García D 148.

\section{STEIRCULIACEAE}

Ayenia insularia Cristobal

Ayenia pusilla L.-Recorded by Britton and Wilson, Vol. V, p. 574. Not seen by us on our first visit but collected later on edge of cliff or ridge on the north coast; not common. Woodbury and Martorell D 75.

\section{Melochia tomentosa L.}

Moluchia tomentosa (L.) Britton-Recorded by Britton and Wilson, Vol. V, p. 571. In open sites along the rocky coasts of the southwest and west and on the top of the ridges on the northern and northeastern coasts. Woodbury and Martorell D 3, D 117.

* Waltheria indica $\mathrm{L}$.

Waltheria americana $\mathrm{L}$.- On a slope in an open site near the coast west of Puerto Canoas; not common. Woodbury, Martorell, García D 60.

\section{GUTTIFERAE}

Clusia rosea Jacq.

Recorded by Britton and Wilson, Vol. V, p. 586. In the interior valleys; several trees also seen on the higher ridges; not common. Woodbury: Martorell, García D 115. 


\section{PASSIFLORACEAE}

\section{Passiffora suberosa $\mathrm{L}$.}

Passiflora pallida L.-Recorded by Britton and Wilson, Vol. V, p. 602. Observed by Smith, Woodbury and Martorell along the rocky coasts west of Puerto Canoas and on top of the ridge on the northeastern coast. Woodbury and Martorell D 133, D 143.

\section{CACTACEA}

\section{Consolea moniliformis (L.) Britton}

Opuntia moniliformis (L.) Haw.-Recorded as endemic to Desecheo and Hispaniola by Britton, Vol. V, p. 611. This common Island species of cacti occurs from the coast to the higher ridges; attacked by the cactus moth, Cactoblastis cactorum (Berg.).

\section{Harrisia portoricensis Britton}

Common along the coustal areas, on mountain slopes and ridges, and in open and barren sites. Not recorded from Desecheo by Britton and Wilson (8), but by Britton and Rose (7). Woodbury, Martorell, García D 152.

\section{Lemaireocereus hystrix ( $\mathrm{H}_{\mathrm{aw}}$ ) Britton}

Recorded by Britton and Wilson, Vol. V, pp. 613-4. Observed by Woodbury, Martorell and García, in 1967 and 1968 along the rocky shores near Puerto de los Botes; fairly common.

Mammillaria nivosa Link

Neomammillaria nivosa (Link) Britton and Rose-This species was not mentioned by Britton and Wilson in their publication ( 8 ) although recorded as occurring on Desecheo in Britton's 1914 report (6), also for this locality in the Britton and Rose (7) studies on the Cactaceae. Woodbury, Martorell and García saw this cactus species commonly on Desecheo, particularly in open sites and on barren areas on ridges, slopes and rocky cliffs. It is a very showy and ornamental species with snowy white heads and conspicuous red fruits (fig. 5). Although not found in Puerto Rico, it occurs on the islands of Culebra and Moni, on some of the Virgin Islands, Antigua and in the Bahamas.

Melocactus intortus (Mill.) Urban

Cactus intortus Mill.--Recorded by Britton and Wilson, Vol. V, p. 617. Observed by Woodbury, Martorell and García during both trips to Desecheo; abundant along the rocky shores and mountain slopes of the north and northeast areas.

\section{* Opuntia dillenii (Ker.-Gawl.) Haw.}

Perhaps the most common cactus species on Desecheo, found from the sea coast to the upper ridges. Attacked by the phytophagous insect, 
Cactoblastis cactorum (Berg), the larvae of which was destroying large colonies of this cactus everywhere on the Island. Observed on both trips. This common species is not listed in Britton and Wilson (8) or in Britton and Rose (7) as occurring on Desecheo.

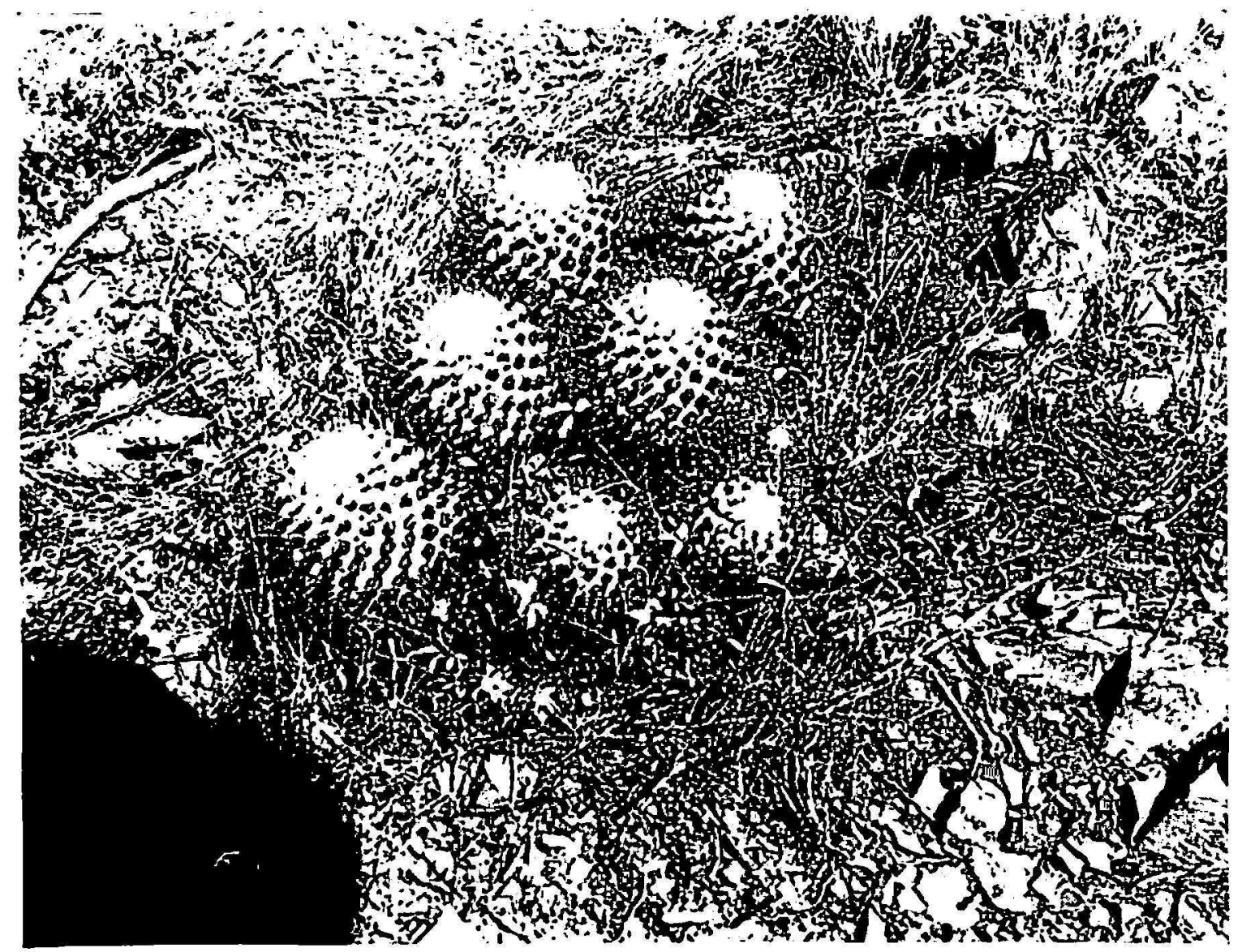

FIG. 5. - The very showy, ornamental cactus, Mammillaria nivosa, with its snowy white heads and conspicunus red fruits, found in Desecheo, also on Mona and Culebra Islands.

\section{* Opuntia repens Bello}

Common particularly in open sites on the top of ridges and along the coast.

Opuntia triacantha (Willd.) Sweet

Recorded by Britton and Wilson, Vol. V, p. 610. Perhaps the second most common cactus species on Desecheo; found from the coastal areas to the high ridges and mountain slopes; it also is attacked by Cactoblastis.

Pilosocereus royeni (L.) Byles and Rowley

Cephalocereus royeni (L.) Britton and Rose-Recorded by Britton and Wilson, Vol. V, p. 612. A very common cactus over all the Island, particularly on the south and southeastern slopes. 
MYRTACEAE

Eugenia axillaris (Sw.) Willd.

Recorded by Britton and Wilson, Vol. VI, p. 36. Found quite abundant in both interior valleys north of Puerto Canoas and Puerto de los Botes; also found on the north ridge. Woodbury, Martorell, García D 34, D 138.

* Eugenia maleolens Poir.

Eugenia buxifolia (Sw.) Willd.-In the valley north of Puerto Canoas reaching trunk diameters of 5 inches and 30 feet in height which is very tall for this particular species; also quite frequent on mountain slopes. Woodbury, Martorell, García D 9, D 140.

Eugenia rhombea (Berg) Iírug and Urban

Recorded by Britton and Wilson, Vol. VI, p. 37. The most common species of the family on Desecheo, particularly in the interior valleys. Woodbury, Martorell, García D 35, D 137.

PLUMBAGINACEAE

\section{* Plumbago scandens L.}

Forming the common underbrush in places in the interior valleys and on the slopes, also seen on the high ridges; in spite of the drought, in almost full flower on April 5, 1967, not quite so during July 1968. Woodbury, Martorell, García D 33, D 43.

\section{SAPOTACEAE}

\section{* Bumelia obovata (Lam.) A. DC.}

In the interior valley north of Puerto Canoas; also on ridge of the northeast coast; not common. Woodbury and Martorell D 28, D 52.

* Bumelia obovata var. krugii (Pierre) Cron.

Bumelia krugii Pierre-This species recorded by Britton as endemic to the southwestern dry districts of Puerto Rico and Vieques, also was found in the interior valleys and ridges of Desecheo. Woodbury and Martorell D 20.

\section{OLEACEAE}

* Foresteria segregata (Jacq.) Krug and Urban

One tree seen April 5, 1967 by Woodbury and Martorell on the north ridge.

\section{ASCLEPIADACEAE}

* Cynanchum cheesmanii Woods.

Metastelma decipiens Schlechter-Along the coast, climbing on shrubs 
and small plants, in southwest areas; fairly common. Woodbury and Martorell, D 149.

* Cynanchum grisebachianum (Schltr.) Alain

Metastelma decaisneanum Schletcher-Twining on low vegetation and shrubs growing along the southwest coast, also observed in the interior valleys and mountain slopes; common. Woodbury, Martorell, García D 92. Matalea maritima (Jacq.) Woods.

Ibatia maritima (Jacq.) Dene.-Recorded by Britton and Wilson, Vol. VI, p. 99. Not seen on Desecheo by us.

\section{CONVOLVULACEAE}

\section{* Ipomoea triloba L.}

At entrance of the small valley north of Puerto de los Botes; common. Woodbury, Martorell, García D 42.

* Ipomea tuba (Schltr.) G. Don

Calonyction tuba (Schltr.) Colla-Rare, growing under the shade of a small sea-grape (Coccoloba uvifera) grove about 200 yards west of Trap Beach in Puerto Canoas. Woodbury, Martorell, García D 71, D 102.

\section{* Jacquemontia nodiflora (Desv.) G. Don}

Not seen in 1967 by Woodbury and Martorell but found in 1968 growing along the rocky shores and twining among the brush and low shrubs; particularly common between Puerto de los Botes and Puerto Canoas.

* Jacquemontia pentantha (Jacq.) G. Don

In the same general area as the species above. Woodbury and Martorell D 139.

\section{BORAGINACEAE}

\section{* Bourreria succulenta Jacq.}

One of the most common trees on the Island, in flower and fruit July $12-13,1968$, in the interior valleys, near the coast, and on slopes and mountain ridges. Woodbury, Martorell, García D 2, D 154.

* Heliotropium angiospermum Murray

Schobera angiosperma Murray-In the interior valley north of Puerto Canoas, also on the rocks and between low shrubbery along the coastal area of the southwest; abundant. Woodbury, Martorell, García D 17, D 153. * Tournefortia microphylla Bert.

Fairly common on the rocky shores, throughout the valleys, and on top of ridges. Woodbury, Martorell, García D 19, D 86.

\section{VERBENACEAE}

\section{Citharexylum fruticosum $\mathrm{L}$.}

Recorded by Britton and Wilson, Vol. VI, pp. 145-6, Abundant in the 
interior valleys, on mountain slopes along the coast, as well as on the upper barren ridges. Woodbury, Martorell, García D 4, D 77.

Duranta repens L.

Recorded by Britton and Wilson, Vol. VI, pp. 146-7. Seen on top of the ridge on the north coast, scattered trees also observed in the valley north of Puerto de los Botes. Woorbury, Martorell, García D 72, D 105.

Lantana involucrata $\mathrm{L}$.

Recorded by Britton and Wilson, Vol. VI, p. 140. On top of the ridge on the north coast, common along the rocky shores of the southwest. Woodbury, Martorell, García D 29, D 58.

\section{SOLANACEAE}

Solanum racemosum Jaccl.

Recorded by Britton and Wilson, Vol. VI, p. 169. A very common plant from the coastal areas to the top of the ridges. Woodbury, Martorell, García D 24, D 45.

\section{BIGNONIACEAE}

\section{Crescentia cujete L.}

Recorded by Britton and Wilson, Vol. VI, p. 198. Not seen by us during our trips to Desecheo. Probably the record may have been based on a single tree that has disappeared.

* Doxantha unguis-cati (L.) Rehder

Batocydia unguis (L.) Mart.-Common in the interior valleys at tached to the trunk of trees, also on the mount ain slopes and ridges, on trees and on the trunks of spiny cacti species. Due to the rainfall just previous to our second trip, this species was very luxuriant and in many cases the vine was completely covering the trees; it is deciduous or semi-deciduous during dry periods. Woodbury, Martorell, García D 13, D 40.

\section{RUBLACEAE}

\section{* Erithalis fruticosa L.}

Observed in flower by Woodbury and Martorell, April, 1967, on top of the ridge in the north coast.

Guettarda elliptica Sw.

Recorded by Britton and Wilson, Vol. VI. A single tree seen in 1967 by Woodbury and Martorell on the eastern slope of the large valley north of Puerto Canoas.

\section{COMPOSITAL}

* Conyza canadensis (L.) Cron. var. pusilla (Nutt.) Cron. Leptilon pusillum (Nutt.) Britton-Fairly abundant in the area west 
of Puerto de los Botes, near the wooden tank and heliport. Woodbury and Martorell D 49.

\section{* Eupatorium odoratum L.}

Osmia odorata (L.)-On top of the ridge at end of large valley north of Puerto Canoas; very rare. Woodbury and Martorell D 21, D 136.

\section{Pectis linifolia $\mathrm{L}$.}

Recorded by Britton and Wilson, Vol. VI, p. 319. Quite common in the interior valleys and also on top of the ridge at the northeast coast. Woodbury, García, Martorell D 41, D 95.

\section{* Sonchus oleraceus $I$.}

Along the coast west of Puerto Canoas; not common. Woodbury and Martorell D 89.

Vernonia albicaulis Pers.

Recorded by Britton and Wilson, Vol. VI, p. 282. Not seen in the Island by us.

* Vernonia cinerea (L.) Less.

Along the coastline and on top of ridges; not very common. Woodbury and Martorell D 30, D 47.

\section{POLYPODIACEAE}

Cheilanthes microphylla Sw.

This fern is recorded by William R. Maxon (18) in Vol. VI, p. 428. Not seen by us but probably present in the area close to the highest peak of the Island which we did not visit.

\section{SUMMARY}

The first section of this paper furnishes a discussion of the origin of the name Desecheo, notes on the geology of the Island, a chronological history of the scientific investigations conducted there and a detailed account of the different plant communities.

The second section is an annotated checklist of the plants of Desecheo, representing 43 families in the Angiosperma and only one in the Gymnosperma. Of 128 plant species hereby recorded, $6 \check{5}$ are new records for Desecheo, the remaining 63 had been mentioned previously in Britton and Wilson, Flora of Porto Riro and the Virgin Islands.

\section{RESUMEN}

Ia primera sección de este trabajo incluye una breve discusión sobre el origen del nombre Desecheo, seguida de una serie de observaciones sobre la geología del lugar, una historia cronológica de las investigaciones científicas que se han llevado a cabo en dicha isla, en el pasado y hasta el 
presente, y, además, una presentación detallada de las fito-comunidades que en ella existen.

La segunda sección consiste de una lista anotada de las especies de plantas de Desecheo, cuya flora está representada por 43 familias de las Angiospermas y una sola de las Gimnospermas. De las 128 especies informadas en este trabajo, 65 son nuevos records para Desecheo, mientras que las restantes 63 han sido previamente mencionadas en la publicación de Britton y Wilson, "Flora of Porto Rico and the Virgin Islands."

\section{LITERATURE CITED}

1. Abbad y Lasierra, Fr. I., Historia geográfica civil y natural de la isla de San Juan Bautista de Puerto Rico, Editorial Universitaria, Univ. P. R., pp. 1-317, 1966. (Original manuseript first published in 1788.)

2. Bowdish, B. S., A day on De Cicheo Island, Oologist 17: 117-20, Sept. 1900.

3. - - Birds of Porto Rico, Auk 19: 356-66, Oct. 1902.

4. - Birds of Porto Rico, A uk 20: 10-23, Jan. 1903.

5. Brau, S., Historia de Puerto Rico, D. Appleton \& Co., N. Y., 1904. (Edición fascimilar por Editorial Coquí, Río Piedras, P. R., 1966.)

6. Britton, N. L., Botanical explorations in Porto Rico and islands adjacent, $J$. New York Bot. Gard. 15: 95-103, 1914.

7. Britton, N. L. and Rose, J. N., The Cactaceae (in 4 volumes bound as 2 ), Dover Publications, Inc., New York, 1963. (Originally published in 1920 as Publ. No. 248, Carnegie Institute of Washington.)

8. Britton, N. L. and Wilson, P., Botany of Porto Rico and the Virgin IslandsDescriptive Flora-Spermatophyta, Sci. Surv. P. R. and the Virgin Is., N. Y. Acad. Sci., 5: $626 \mathrm{pp} .$, and 6: 663 pp., 1923-30.

9. Coll y Toste, C., Vocabulario de palabras introducidas en el idioma español procedentes del lenguaje indo-antillano, Bol. Histórico de P.R., Tomo VIII, pp. 294-352, 1921.

10. Danforth, S., Puerto Rican ornithological records, Dept. Agr. P. R. 15 (1): 33106, Jan. 1931.

11. Gundlach, J., Apuntes para la fauna Puerto-Riqueña, Anal. Soc. Esp. Hist. Nat., Madrid VII, (Aves, pp. 141-234, 343-422), 1878.

12. Hubbard, B., The geology of the Lares District, Porto Rico, Sci. Surv. Porto Rico and the Virgin Islands, N. Y. Acad. Sc., 2(1): 1-115, 1923.

13. Keroher, G. C., Lexicon of geologic names of the United States, U.S. Geol. Surv., Bull. 1200, p. 1097, Washington, 1966.

14. Labat, J. B., Voyage aux Iles de l'Amerique, contenant l'Histoire Naturelle de ces Pays, l'Origine, le Moeurs, la Religion et le Gouvernement des Habitants Anciens et Modernes (New Edition, 8 vols., Paris 1842.) (Originally published in Paris, France, in 1724.)

15. Liogier, A. II., Nomenclatural changes and additions to Britton and Wilson's "Flora of Puerto Rico and the Virgin Islands", IRhodora 67 (772): 315-61, 1965.

16. - - Further changes and additions to the Flora of Porto Rico and the Virgin Islands, Rhodora 69 (779): 372-76, 1967.

17. Ioebeck, A. K., The physiography of Porto Rico, Sci. Surv. of Puerto Rico and the Virgin Islands, N. Y. Acad. Sc., 1 (4) : 301-84, 1922.

18. Maxon, W. R., Botany of Porto Rico and the Virgin Islands-Descriptive Flora-Pteriodophyta, Sci. Surv. of Porto Rico and the Virgin Islands, N. Y., Acad. 
Sc., $6: 373-521,1926$. (Separate, as Pterydophyta of Porto Rico and the Virgin Islands.)

19. Myers, R. E., pers. comm., Feb. 20, 1969.

20. Seiders, V. M., pers. comm., March, 71969.

21. Struthers, P. H., Observations on the bird life of Porto Rico, Auk 40:469-78, 1923.

22. Wetmore, A., Birds of Porto Rico, USDA Bull. 326, Washington, D.C., pp. 1-140, March 24, 1916.

23. - The birds of Porto Rico and the Virgin Islands-Colymbiformes to Columbiformes, Sci. Surv. of Porto Rico and the Virgin Islands, N. Y. Acad. Sc. 9 (3): 245-403, 1927. 